\title{
ARTICLE
}

\section{Mutational analysis of PAX6: 16 novel mutations including 5 missense mutations with a mild aniridia phenotype}

\author{
Karen Grønskov ${ }^{1}$, Thomas R osenberg ${ }^{2}, A$ nnie Sand ${ }^{1}$ and $K$ aren Brøndum-N ielsen ${ }^{1}$ \\ ${ }^{1}$ D epartment of M edical G enetics, J ohn F K ennedy Institute, G lostrup \\ ${ }^{2} \mathrm{~N}$ ational E ye Clinic for the Visually I mpaired, H ellerup, D enmark
}

\begin{abstract}
Mutations in the developmental control gene PAX6 have been shown to be the genetic cause of aniridia, which is a severe panocular eye disease characterised by iris hypoplasia. The inheritance is autosomal dominant with high penetrance but variable expressivity. $\mathrm{H}$ ere we describe a mutational analysis of $27 \mathrm{D}$ anish patients using a dideoxy fingerprinting method, which identified PAX6 mutations in 18 individuals with aniridia. A thorough phenotype description was made for the 18 patients. A total of 19 mutations, of which 16 were novel, are described. A mong these were five missense mutations which tended to be associated with a milder aniridia phenotype, and in fact one of them seemed to be non-penetrant. Four of the five missense mutations were located in the paired domain. We also describe a third alternative spliced PAX 6 isoform in which two of the four missense mutations would be spliced out. 0 ur observations support the concept of dosage effects of PAX6 mutations as well as presenting evidence for variable expressivity and gonadal mosaicism.
\end{abstract}

Keywords: PAX6; aniridia; phenotype-genotype correlation; missense mutations; alternative splicing

\section{Introduction}

A niridia is a severe panocular disorder, with a reported incidence of 1 in 50000 to 100000 . The disease is characterised by lack of iris development, often associated with cataracts, optic nerve hypoplasia and glaucoma. Severe age-related corneal degeneration is a frequent complication which contributes to a poor visual prognosis in aniridia. A bout one third of the cases are sporadic, and two thirds are familial, with an autosomal dominant inheritance, with high penetrance,

Correspondence: Karen Brøndum-Nielsen, Department of M edical G enetics, John F K ennedy Institute, G I. L andevej 7, D K-2600 G lostrup, D enmark. Tel: + 45432601 00; Fax: +45 434311 30; E-mail: kbn@jfk.kennedy.dk

R eceived 26 A ugust 1998; revised 9 N ovember 1998; accepted 19 N ovember 1998 but variable expressivity. ${ }^{1}$ The sporadic cases can be part of the WA GR syndrome (Wilms' tumour, aniridia, genitourinary abnormalities and mental retardation) caused by a chromosomal deletion in the 11p13 region. $^{2}$

The human PAX 6 gene was cloned in 1991 by positional cloning, ${ }^{3}$ and has been isolated from both vertebrates and invertebrates including mouse, ${ }^{4,5}$ quail, ${ }^{6}$ rat, ${ }^{7}$ chicken, ${ }^{8}$ zebrafish, ${ }^{9,10}$ D rosophila melanogaster, ${ }^{11}$ sea urchin ${ }^{12}$ Caenorhabditis elegans, ${ }^{13,14}$ ribbonworm L ineus sanguineus, ${ }^{15}$ ascidian P hallusia mammillata ${ }^{16}$ and $X$ enopus laevis. ${ }^{17}$

The human PAX 6 gene spans $22 \mathrm{~kb}$ and consists of 14 exons. ${ }^{18}$ The encoded protein contains two DNA binding domains, the paired box of 128 amino acids and a paired-type homeobox of 61 amino acids, separated 
by the linker region. The paired domain has two functional subdomains, the 74 amino acid $\mathrm{N}$-terminal domain which is relatively conserved among paired domains, and the less well conserved 54 amino acid $\mathrm{C}$-terminal domain. ${ }^{19} \mathrm{PA} \times 6$ is alternatively spliced and inclusion of exon 5a (PAX 6-5a) alters the D NA binding properties resulting in DNA contact by the $\mathrm{C}$-terminal domain instead of the $\mathrm{N}$-terminal domain. ${ }^{19}$ Five different alternative spliced products have been identified in the bovine eye, ${ }^{20}$ and several isoforms have also been reported in quail. ${ }^{21}$

Furthermore, in the $\mathrm{C}$-terminal part of the protein there is a proline, serine and threonine rich (PST) domain of 152 amino acids ${ }^{3}$ which resembles the activation domain of transcription factors CTF-1 (CA A T-box binding transcription factor) ${ }^{22}$ and $0 \mathrm{ct} 2,{ }^{23}$ and has been shown to possess transcriptional activity in vitro. ${ }^{12,24,25}$ Q uail Pax-6 has been shown to transactivate its own promoter, ${ }^{26}$ and Pax- 6 from mouse, chicken and guinea pig was shown to be involved in transcriptional regulation of crystallin genes. ${ }^{27}$ Pax- 6 belongs to the Pax family of developmental control factors ${ }^{28}$ all possessing the paired domain originally identified in the D rosophila melanogaster segmentation gene paired. ${ }^{29} \mathrm{~A}$ striking amino acid identity is observed of Pax- 6 proteins between species, especially in the functional domains, with only one amino acid difference between the mouse and the human gene located in the alternatively spliced exon. ${ }^{4,18}$ The expression patterns of Pax- 6 are also conserved throughout the vertebrates, ${ }^{27}$ and transcripts have been detected in the developing eye, the brain and pancreas. ${ }^{3}$

Based on findings in the small eye (Sey) mouse, ${ }^{30}$ mutations in PAX 6 were identified as the genetic cause of aniridia, and in the human PAX 6 database there are reports of 118 mutations. $^{31,32}$ Most of the mutations cause premature truncation of the protein, and only six missense mutations have been reported. Two of these are associated with classical aniridia, $\mathrm{R}^{208 \mathrm{~W}^{33}}$ and I87R, ${ }^{34}$ whilst the other four are associated with variable phenotypes; $\mathrm{G} 18 \mathrm{~W}$ caused congenital cataract (in the proband) and Peter's anomaly (in the mother) (PAX 6 mutation database ${ }^{31}$ ), R 26G caused Peter's anomaly, ${ }^{35}$ R $128 \mathrm{C}$ caused foveal hypoplasia ${ }^{36}$ and Q 422R caused ocular anterior segment anomalies. ${ }^{37} Y$ et another phenotype, autosomal dominant keratitis, has been associated with a splice site mutation (IVS10$2 A>T$ ) in PAX $6 .^{38}$

$\mathrm{H}$ ere, we report a mutational analysis of PAX 6 in $27 \mathrm{D}$ anish patients using dideoxy fingerprinting and
DNA sequencing. 19 mutations were detected, including five new missense mutations, which tended to be associated with milder iris phenotypes.

\section{Subjects and Methods}

\section{Patients}

A total of 27 patients was investigated of whom 23 had aniridia, three had congenital cataract without aniridia, and one Peter's anomaly. The patients had no major chromosomal alterations or deletions in $11 \mathrm{p} 13$ as shown by conventional cytogenetic analysis (Q-banding), and FISH analysis using probes for PAX 6 and WT1. A short summary of the phenotype is shown in Table2, and more detailed clinical case stories can be seen in the A ppendix. $\mathrm{E}$ ach patient was given a score from 1 to 6 based on the severity of the aniridia, with iris 1 being stromal hypoplasia with centrally located pupil, iris 2 stromal hypoplasia with eccentric pupil, iris 3 circumpupillary aplasia, iris 4 atypical sector coloboma ( $<$ half circumference absent), iris 5 subtotal aniridia ( $>$ half circumference absent) and iris 6 complete aniridia (Figure 1).

The patient data were extracted from the medical files at the National Eye Clinic. Most patients were followed for several years and since some of the phenotypic characteristics (eg corneal dystrophy) are age-related, the birth years and the age at examination are indicated in the case reports. O bservations from other eye departments and ophthalmologists in private practice were included in some cases.

\section{DNA Extraction, PCR and Dideoxy Fingerprinting}

Genomic DNA was isolated from blood leukocytes using standard salting out method. ${ }^{39}$ Primers used in the study are shown in Table 1. ${ }^{18,40}$ A nnealing temperatures for the PCR amplification are shown in Table 1, and the cycling profile was for all exons: an initial denaturation at $95^{\circ} \mathrm{C}$ for $5 \mathrm{~min}$ followed by $30 \mathrm{cycles}$ of $95^{\circ} \mathrm{C}(30 \mathrm{~s})$, annealing temperature (30s), $72^{\circ} \mathrm{C}(30 \mathrm{~s})$. A final extension step at $72^{\circ} \mathrm{C}$ for $7 \mathrm{~min}$ ended the protocol. A mplification was done in standard PCR buffer, using 0.011 units/ $\mu$ I A mpliTaq Gold polymerase from Perkin EImer (California, USA) $50 \mu \mathrm{m}$ of each dATP, dCTP, dGTP, dTTP and $0.4 \mu \mathrm{m}$ of each primer.

For the mutation analysis, a sequencing reaction using one of the four dideoxy-nucleotides was performed for each exon (method modified from Sarker et al $1992^{41}$ ). The sequencing product was analysed on a non-denaturing $0.5 \times \mathrm{MDE}$ gel. Some of the exons were analysed twice with two different dideoxy nucleotides. If a shift in mobility was observed the PCR product was sequenced using the same primers as used for $P C R$ and dideoxy fingerprinting.

Exon 13 was analysed by DNA sequencing using the $13 F$ primer of the PCR product made by primers $13 \mathrm{~F}$ and $13 \mathrm{R}$. DNA sequencing was done using the cycle-sequencing kit from A mersham (U ppsala, Sweden) according to the manufacturer's instructions. A II single nucleotide substitutions, except when located in splice sites, were confirmed by sequencing a second PCR product.

\section{$R T$-PCR of Illegitimate Transcripts in Lymphoblastoid Cells}

Total R NA was isolated from E pstein-Barr virus transformed lymphocytes from patients with splice site mutations and 

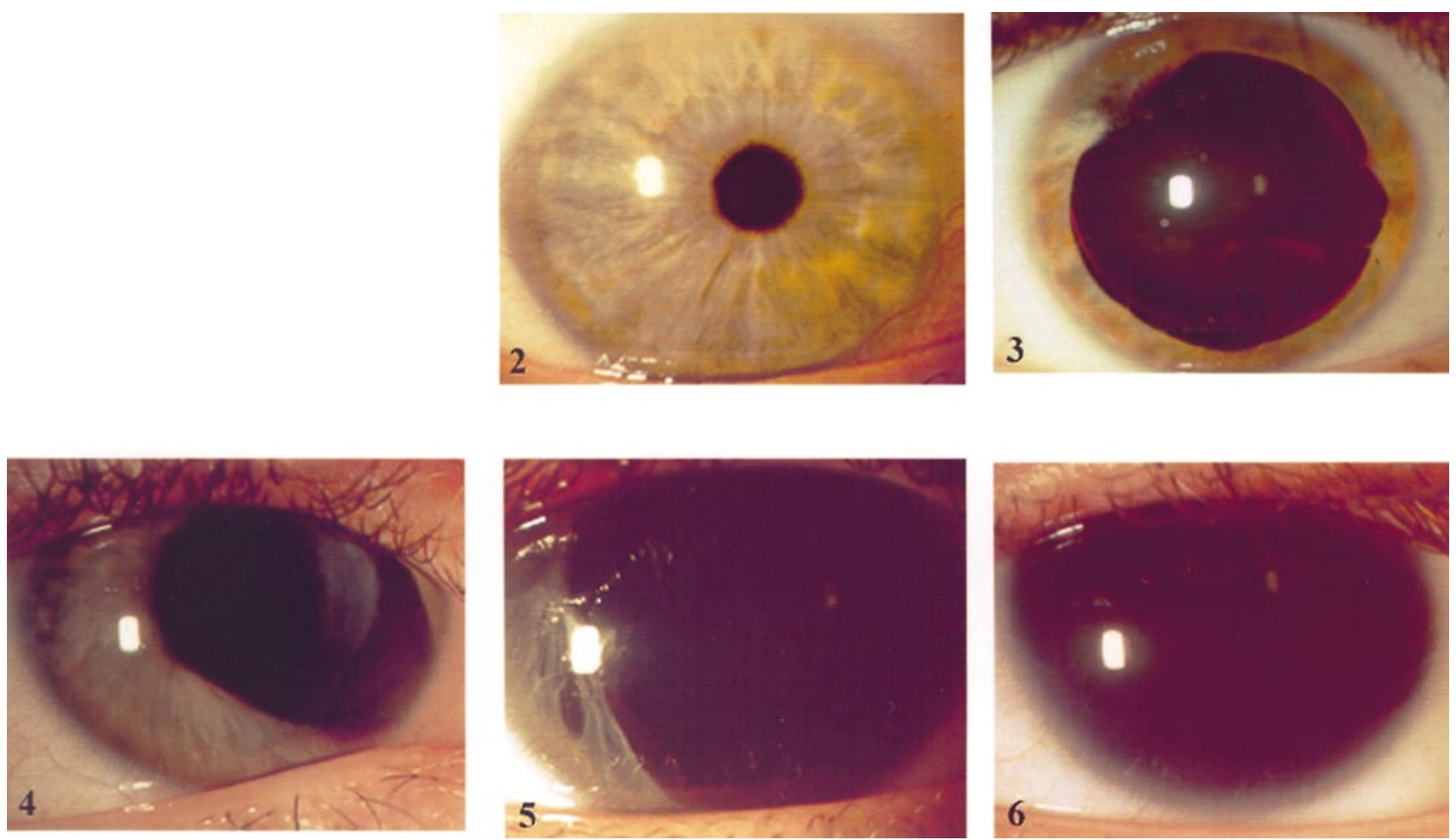

Figure 1 Classification of aniridia phenotypes. (I ris 1 was not observed in this series). I ris 2: stromal hypoplasia with eccentric pupil; I ris 3: circumpupillary aplasia; I ris 4: atypical sector coloboma; I ris 5: subtotal anirida; I ris 6: complete aniridia

normal controls, using the R Neasy mini kit from Qiagen (H ilden, G ermany) following the manufacturer's instructions. The RNA (approximately $10 \mu \mathrm{g}$ ) was treated with 10 units DNasel (A mplification grade from Gibco, Life Science ( $M$ aryland, USA )), following the manufacturer's instructions. $1 \mu \mathrm{g}$ of total RNA was reverse transcribed using random hexamer primers and the Superscriptll enzyme from Gibco (Life Science) following the manufacturer's instructions.

N ested RT-PCR was performed of two regions. Fragment 1 from nucleotide -51 to 962 and fragment 2 from nucleotide 1248 to 1622 , nucleotide numbers according to Ton et al, $^{3}$ using the following primers listed.

Fragment 1 first PCR : forward primer: $1 F$ : 5'-CA G AGG TCA GGC TTC GCT AA-3', reverse primer C130: 5'-CTT TCT CCA GGG CCT CAA T-3'. ${ }^{33}$ Nested PCR: forward: 4F-N: 5'-GGT CAG GCT TCG CTA ATG GG-3' reverse primer C 860: 5'-AGC CTC ATC TGA ATC TTC TCC -3' ${ }^{33}$

Fragment 2 first PCR : forward primer 1300F : 5'-G TC TA C CA A CCA ATT CCA CAA CC-3', reverse primer 1680R: 5'-TAA TCT TGG CCA GTA TTG AGA CAT ATC-3'. Nested PCR : forward primer: $1303 \mathrm{~F}-\mathrm{N}$ : $5^{\prime}-\mathrm{A}$ CC A AC CA A TTC CAC AAC CCA CC-3', reverse primer: 1677R-N: 5'-CTT GGC CAG TAT TGA GAC ATA TCA GGT-3'.

Two $\mu \mathrm{l} \mathrm{CDNA}$ was amplified in a $20 \mu \mathrm{l}$ volume in standard PCR buffer, $250 \mu \mathrm{m}$ of each dATP, dCTP, dGTP and dTTP, $0.5 \mathrm{um}$ of each primer, and 1.5 units $\mathrm{A}$ mpliqTaq $\mathrm{G}$ old from Perkin EImer. The DNA was initially denatured for $7 \mathrm{~min}$ at $95^{\circ} \mathrm{C}$, followed by $35 \mathrm{cycles}$ of denaturing at $95^{\circ} \mathrm{C}$ for $30 \mathrm{~s}$, annealing at $55^{\circ} \mathrm{C}$ for $45 \mathrm{~s}$ and extension at $72^{\circ} \mathrm{C}$ for $3 \mathrm{~min}$ ( $1 \mathrm{~min} 30 \mathrm{~s}$ for fragment 2). The amplification was ended by a final extension at $72^{\circ} \mathrm{C}$ for $5 \mathrm{~min}$. O ne $\mu$ l of this PCR reaction was amplified using the nested primers in a $20 \mu \mathrm{l}$ volume in standard PCR buffer, $125 \mu \mathrm{m}$ of each dATP, dCTP, dG TP and dTTP, $0.5 \mu \mathrm{m}$ of each primer and 1 unit of A mpliTaq Gold. The DNA was denatured initially for $7 \mathrm{~min}$ at $95^{\circ} \mathrm{C}$, followed by 35 cycles of amplification with denaturing at $95^{\circ} \mathrm{C}$ for $30 \mathrm{~s}$, annealing for $45 \mathrm{~s}$ at $55^{\circ} \mathrm{C}$ and extension at $72^{\circ} \mathrm{C}$ for 2 min and a final extension at $72^{\circ} \mathrm{C}$ for $5 \mathrm{~min}$. The products were visualised on ethidium bromide stained agarose gels.

\section{Identification of PAX6 Isoforms in Human Brain cDNA by RT-PCR}

Primers IF and C130 (see above) were used for the initial PCR as described using 2 ng human brain, cerebellum $Q$ uickclone CDNA from Clontech (California, USA). $0.5 \mu$ l of this PCR product was amplified using nested primers: $C 127$ : 5'-GCC AGA GCC AGC ATG CAG AAC-3', ${ }^{33}$ C 860 (see above), C141: 5'-CCA TGC AGA TGC AAA AGT CC-3', 5aR: 5'-GCA CTT GGA CTT TTG CAT CTG-3', 640R: 5'-TAC TAC CAC CGA TTG CCC TG-3'. The conditions were as for the initial reaction. $B$ ands were excised from the gel, left in $50-100 \mu \mathrm{l} \mathrm{H}_{2} \mathrm{O}$ overnight and $13.5 \mu \mathrm{l}$ sequenced using A mersham's cycle sequencing and primer $876 \mathrm{R}-\mathrm{N}$ : 5'-GGT CTG CCC GTT CAA CAT CC-3'.

\section{Results}

M utational analysis of PAX 6 by dideoxy fingerprinting and DNA sequencing revealed mutations in 18 patients (Figure 2 and Table2). A total of 19 mutations were found, of which 16 are novel. We also found an already 
Table 1 Primers used for dideoxy fingerprinting

\begin{tabular}{|c|c|c|c|c|c|}
\hline Exon & Primer name & Sequence, $5^{\prime}-3^{\prime}$ & U sage & Size (bp) & A nneal. temp \\
\hline 1 & $1 \mathrm{~F}$ & CTC ATT TCC CGC TCT G GT TC & $P C R$ and $d d F$ & 197 & $62 \stackrel{\circ}{ } \mathrm{C}$ \\
\hline 1 & IR B & A A G AGT GTG GGT GAG GGA AGT & PCR & & \\
\hline 1 & IR S & TGT GGG TGA GGG AAG TGG CTG (a) & $\mathrm{ddF}$ & & \\
\hline 2 & $2 \mathrm{~F}$ & TTA TCT СТС ACT СТC CAG CC & PCR & 276 & $60 \circ \mathrm{C}$ \\
\hline 2 & $2 \mathrm{R}$ & AAG CGA GAA GAA AGA AGCGG & PCR & & \\
\hline 2 & $2 \mathrm{~F} 2$ & CAC TCT CCA GCC GCT GACAG (a) & $d d F$ & & \\
\hline 2 & $2 \mathrm{R} 2$ & CGA GAA GAA AGA AGC GGA CT (a) & $\mathrm{ddF}$ & & \\
\hline 3 & $3 F$ & TCA GAG AGC CCA TCG ACG TAT & $P C R$ and $d d F$ & 193 & $60 \cong \mathrm{C}$ \\
\hline 3 & $3 R$ & CTG TTT GTG GGT TTT GA G CC & $P C R$ and $d d F$ & & \\
\hline 4 & $4 \mathrm{~F}$ & TTG GGA GTT CA G CC TAC CT & $P C R$ and $d d F$ & 153 & $58 \div \mathrm{C}$ \\
\hline 4 & $4 \mathrm{R}$ & GAA GTC CCA GAA AGA CCA GA & $P C R$ and $d d F$ & & \\
\hline 5 & $5 F 2$ & ССT CTT CAC TCT GCT CTC TT & PCR & 284 & $60^{\circ} \mathrm{C}$ \\
\hline 5 & $5 F 3$ & CA G TCT GCT CTC TTC TCT TCT TT (a) & $\mathrm{ddF}$ & & \\
\hline 5 & $5 \mathrm{R} 2$ & ATG AAG AGA GGG CGT TGA GA & $d d F$ & & \\
\hline 5 & $5 \mathrm{R} 4$ & CAT AAT TAG CAT CGT TTA CAG TAA (a) & PCR & & \\
\hline $5 A$ & $5 A F$ & TGA A A G TAT CAT CAT ATT TGT A G & $P C R$ and $d d F$ & 237 & $58 \stackrel{\circ}{C}$ \\
\hline $5 \mathrm{~A}$ & $5 A R$ & GGG AAG TGGACA GAA A AC CA & $P C R$ and $d d F$ & & \\
\hline 6 & $6 \mathrm{~F}$ & GTG GTT TTC TGT CCA CTT CC & $P C R$ and $d d F$ & 299 & $60^{\circ} \mathrm{C}$ \\
\hline 6 & $6 \mathrm{R}$ & A G G A G GAG CATTGG GCT TA & PCR and ddF & & \\
\hline 7 & $7 F$ & CA G GA G A CA CTA CCA TTT G G & $P C R$ and $d d F$ & 252 & $60^{\circ} \mathrm{C}$ \\
\hline 7 & $7 \mathrm{R}$ & ATG CAC ATA TGG AGA GCT GC & $P C R$ and ddF & & \\
\hline 8 & $8 \mathrm{~F}$ & GGG AAT GTT TTG GTG A G G CT & PCR and ddF & 371 & $60^{\circ} \mathrm{C}$ \\
\hline 8 & $8 \mathrm{R}$ & CAA A GG GCC CTG GCT AA A TT & $P C R$ and $d d F$ & & \\
\hline 9 & $9 F$ & GTA GTT CTG GCA CAA TAT GG & $P C R$ and $d d F$ & 206 & $58 \div \mathrm{C}$ \\
\hline 9 & $9 \mathrm{R}$ & GTA CTC TGT ACA A GC ACC TC & $P C R$ and $d d F$ & & \\
\hline 10 & $10 \mathrm{~F}$ & GTA GACACA GTG CTA ACC TG & PCT and ddF & 243 & $60^{\circ} \mathrm{C}$ \\
\hline 10 & 10R & CCC GGA GCA AACAGG TTTAA & $P C R$ and $d d F$ & & \\
\hline 11 & $11 \mathrm{~F}$ & TTA A AC CTG TTT GCT CCG GG & $P C R$ and $d d F$ & 208 & $60 \div \mathrm{C}$ \\
\hline 11 & $11 R$ & TTA TGCAGG CCA CCA CCA GC & $P C R$ and $d d F$ & & \\
\hline 12 & $12 \mathrm{~F}$ & GCT GTG TGA TGT GTT CCT CA & $P C R$ and $d d F$ & 228 & $60 \div \mathrm{C}$ \\
\hline 12 & $12 R$ & TGC A GC CTG CAG AAA CAG TG & $P C R$ and $d d F$ & & \\
\hline 13 & $13 \mathrm{~F}$ & CAT GTC TGT TTC TCA A A G GGA (b) & PCR and sequencing & 393 & $60^{\circ} \mathrm{C}$ \\
\hline 13 & 13R 2 & CAC CA A A T GAA TAA AAG TTT G (b) & PCR & & \\
\hline
\end{tabular}

Primer sequences and annealing temperatures used in the dideoxy fingerprinting analysis. Primers were from G laser et al, ${ }^{18}$ except (a) which we designed outselves and (b) which were H P6-11up and H P6-12down from M aas et al. ${ }^{40}$

known polymorphism in intron 9 in two patients, ${ }^{42}$ and a silent mutation in exon 10.

Twelve mutations were single nucleotide substitutions of which six were missense mutations, three were nonsense mutations and the remaining three were located in introns, and would be expected to cause splice errors. Two of the nonsense mutations were identical. Six of the mutations were deletions or insertions that were predicted to cause frameshifts, and finally we found a $4 \mathrm{bp}$ deletion in the $5^{\prime}$ untranslated region ( $5^{\prime} U T R$ ) in exon 3 . In the patients in whom we did not observe any shifts in band mobility in the dideoxy fingerprinting analysis, we performed DNA sequencing of selected exons (exon 4 (in all but one), 5 , 6, 7 (in three patients), 8, 10,11 and 12 (in all but one)). With this strategy we identified one additional mutation (in case 29).
We did not detect mutations in PAX 6 in the three patients with congenital cataract, in the patient with Peter's anomaly, nor in five patients with aniridia.

\section{Missense and Nonsense Mutations}

In case 4 we found two missense mutations, one in exon 6 in the paired domain $(598 \mathrm{C}>\mathrm{A})$ changing alanine 79 to glutamic acid (A 79E), and the second in exon 8 in the linker region ( $985 G>A$ ) changing codon 208 from arginine to glutamine ( $R 208 Q$ ). Sequencing of the parents' PAX 6 genes showed that the unaffected mother carried the R $208 \mathrm{Q}$ mutation, whilst the affected father possessed the $\mathrm{A} 79 \mathrm{E}$ mutation. Care was taken to assure that no sample switch had taken place, by repeating the sequencing, and by checking that samples were $X X$ and $X Y$ respectively, using PCR amplification of the amelogenin gene (data not shown). Two affected 


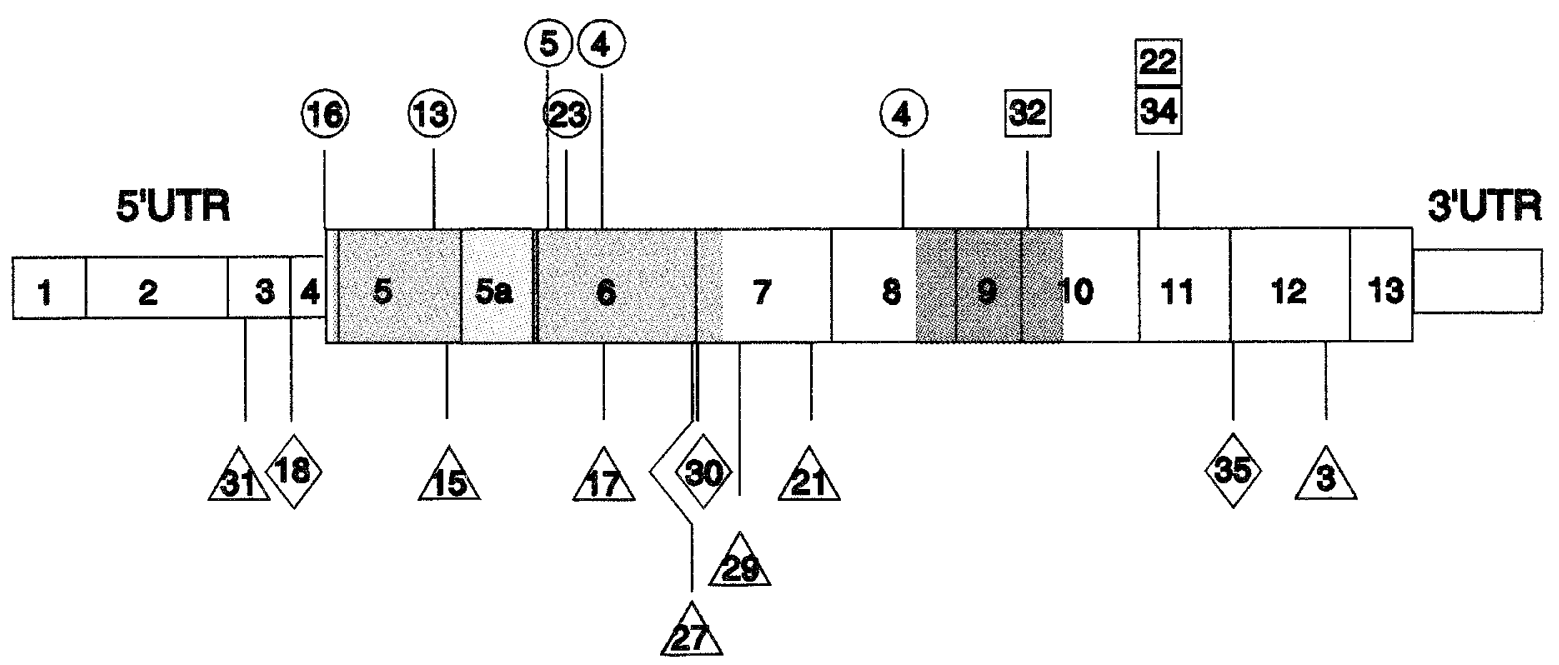

Figure 2 L ocalisation and type of mutations. Circles are missense mutations, squares are nonsense mutations, triangles are deletions/ insertions and diamonds are splice mutations. The polymorphism and the silent mutation are not shown. The light grey box in exons5, $5 a, 6$ and some of exon 7 indicates the position of the paired domain (the alternatively spliced 5a exon is shaded in a lighter grey), whilst the darker grey box in some of exon 8, exon 9 and some of exon 10 indicates the position of the homeodomain

siblings had both mutations like the index patient. The alanine 79 residue has been conserved in all investigated PAX 6 genes. However, in a comparison of the paired domains from 14 representative $P a x$ genes (PAX 1, PAX2, PAX3, PaX-4, PAX5, PAX6, PAX7, PAX 8, PAX 9, prd, G sbn, Gsb, Poxmeso, Poxn) alanine 79 is conserved in nine of them, whilst it is replaced with an threonine in the remaining five; it has not been found to make DNA contact. ${ }^{43}$ The arginine 208 has been conserved in all cloned PAX 6 genes.

A nother missense mutation was found in case 5 in exon 6 in the paired domain (519G >C) changing valine 53 to leucine ( $V 53 \mathrm{~L}$ ). This valine is conserved in all investigated PAX 6 genes, and also in the 14 representative paired domains; it does not seem to make DNA contact. ${ }^{43}$ Family studies showed that the affected mother possessed the mutation, whilst the healthy father did not.

In case 13 a $487 T>G$ substitution was found in the paired domain in exon 5 changing isoleucine 42 to serine (I42S). This isoleucine has been conserved in all investigated PAX 6 genes and also in the 14 abovementioned paired domains, but it does not seem to make D NA contact. ${ }^{43}$ In this family it was not possible to make segregation analysis.

In case 16 we found a mutation in exon 4 of the start codon changing the ATG codon for methionine to A A G which is the codon for lysine (M IK).

Finally, in case 23 a missense mutation was found in exon 6 in the paired domain changing threonine 63 to proline $(\mathrm{T} 63 \mathrm{P})$ due to a $549 \mathrm{~A}>\mathrm{C}$ substitution. This residue is also conserved both in all PAX 6 genes and in the 14 paired domains but has not been found to make DNA contact. ${ }^{43}$ We did not have the opportunity to investigate this family further.

Cases 22 and 34 possessed the same nonsense mutation R 317X $(1311 \mathrm{C}>\mathrm{T})$, which has previously been identified in four other non-related patients. $31,42,44,45$

We also found a novel nonsense mutation in the homeobox domain in case 32 changing codon 261 CGA for arginine to the stopcodon TGA (R 261X) $(1143 \mathrm{C}>\mathrm{T})$.

\section{Splice Mutations}

The dideoxy fingerprinting displayed three nucleotide substitutions located in splice sites, which would be predicted to cause splice errors.

We found a substitution in the 5 ' splice site of intron 3 (IVS3 + IG > A) in case 18. RT-PCR analysis of fragment 1 showed a deviating $700 \mathrm{bp}$ fragment in addition to three larger fragments also observed in controls (Figure 3A). The larger fragments correspond to alternatively spliced forms of PAX 6 (see below). ${ }^{18,20}$ The smaller fragment was excised from the gel and left in $\mathrm{H}_{2} \mathrm{O}$ overnight and subjected to DNA sequencing using the same primers as for the nested PCR. This showed skipping of exons $3,4,5$ and $5 a$. Since exon 4 contains the translation start site no protein synthesis would be expected from this allele.

A nother splice mutation was found in the $5^{\prime}$ splice site of intron 11 (IVS11 + 1G > A) in case 35. RT-PCR analysis of fragment 4 showed amplification of two 
Table 2 O verview of PAX 6 patients and mutations

\begin{tabular}{|c|c|c|c|c|c|c|c|c|}
\hline Patient & Phenotype & $\begin{array}{l}\text { Familial/ } \\
\text { sporadic }\end{array}$ & $\begin{array}{l}\text { Exon/ } \\
\text { intron }\end{array}$ & D omain & Type & Nucleotide & Codon & Outcome \\
\hline $\begin{array}{l}4 \\
(26929)\end{array}$ & $\begin{array}{l}\text { I ris } 2 \\
\text { mild mystagmus, early cataract }\end{array}$ & Familial & $\begin{array}{l}E \times 6 \\
E \times 8\end{array}$ & $\begin{array}{l}\text { Paired } \\
\text { Linker }\end{array}$ & $\begin{array}{l}\text { Substitution } \\
\text { Substitution }\end{array}$ & $\begin{array}{l}598 C-A^{a} \\
985 G-A^{a}\end{array}$ & $\begin{array}{l}\text { A 79E } \\
\text { R 208Q }\end{array}$ & $\begin{array}{l}M \text { issense } \\
M \text { issense }\end{array}$ \\
\hline $\begin{array}{l}\mathbf{5} \\
(25920)\end{array}$ & $\begin{array}{l}\text { Iris } 3 \\
\text { moderate photophobia }\end{array}$ & Familial & Ex6 & Paired & Substitution & 519G -C & V 53L & M issense \\
\hline $\begin{array}{l}13 \\
(20537)\end{array}$ & $\begin{array}{l}\text { I ris 3-4 } \\
\text { intermediate nystagmus, congenital cataract, mild } \\
\text { corneal dystrophy, moderate photophobia }\end{array}$ & Familial & Ex5 & Paired & Substitution & $487 \mathrm{~T}-\mathrm{G}^{\mathrm{a}}$ & 1425 & $M$ issense \\
\hline $\begin{array}{l}16 \\
(19714)\end{array}$ & $\begin{array}{l}\text { I ris } 6 \\
\text { intermediate nystagmus, lens ectopia, late cataract, } \\
\text { mild corneal dystrophy, moderate photophobia, } \\
\text { glaucoma }\end{array}$ & Familial & Ex4 & $\begin{array}{l}\text { Start } \\
\text { codon }\end{array}$ & Substitution & $364 T-A^{a}$ & M $1 K$ & M issense \\
\hline $\begin{array}{l}23 \\
(19597)\end{array}$ & $\begin{array}{l}\text { I ris } 2 \\
\text { intermediate nystagmus, early cataract, mild corneal } \\
\text { dystrophy, glaucoma }\end{array}$ & Familial & $E \times 6$ & Paired & Substitution & $549 \mathrm{~A}-\mathrm{C}^{\mathrm{a}}$ & T63P & M issense \\
\hline $\begin{array}{l}22 \\
(17281)\end{array}$ & $\begin{array}{l}\text { I ris } 6 \\
\text { intermediate nystagmus, lens ectopia, severe corneal } \\
\text { dystrophy }\end{array}$ & Familial & Ex11 & PST & Substitution & $1311 C-T$ & R $317 X$ & Nonsense $e^{31,42,44,45}$ \\
\hline $\begin{array}{l}34 \\
(30041)\end{array}$ & $\begin{array}{l}\text { I ris } 3 \\
\text { pronounced nystagmus, mild corneal dystrophy, } \\
\text { mild photophobia }\end{array}$ & Sporadic & Ex11 & PST & Substitution & $1311 C-T$ & R $317 X$ & Nonsense $\mathrm{si}^{31,42,44,45}$ \\
\hline $\begin{array}{l}32 \\
(29865)\end{array}$ & $\begin{array}{l}\text { I ris } 6 \\
\text { intermediate nystagmus, mild corneal dystrophy, } \\
\text { severe photophobia }\end{array}$ & Familial & Ex10 & Homeo & Substitution & $1143 C-T^{a}$ & R 261X & Nonsense \\
\hline $\begin{array}{l}18 \\
(18999)\end{array}$ & $\begin{array}{l}\text { I ris } 5 \\
\text { mild nystagmus, early cataract, mild corneal } \\
\text { dystrophy, glaucoma }\end{array}$ & Familial & $\begin{array}{l}\text { IVS3 } \\
\text { IVS9 }\end{array}$ & & $\begin{array}{l}\text { Substitution } \\
\text { Substitution }\end{array}$ & $\begin{array}{l}\text { IV S3+1G-A } \\
\text { IV S9-12C-T }\end{array}$ & & $\begin{array}{l}\text { Splice error } \\
\text { K nown polymorphism }\end{array}$ \\
\hline $\begin{array}{l}30 \\
(29712)\end{array}$ & $\begin{array}{l}\text { I ris } 6 \\
\text { intermediate nystagmus, lens ectopia, early cataract, } \\
\text { mild corneal dystrophy, mild photophobia, glaucoma }\end{array}$ & Familial & IVS6 & & Substitution & IV S6+1G -A & & Splice error ${ }^{33}$ \\
\hline $\begin{array}{l}35 \\
(30313)\end{array}$ & $\begin{array}{l}\text { I ris } 5 \\
\text { mild nystagmus, severe corneal dystrophy, moderate } \\
\text { photophobia }\end{array}$ & Familial & IVS11 & & Substitution & IV S11+1G $-A^{a}$ & & Splice error \\
\hline $\begin{array}{l}3 \\
(28247)\end{array}$ & $\begin{array}{l}\text { I ris } 3 \\
\text { mild nystagmus, congenital cataract, severe corneal } \\
\text { dystrophy, glaucoma }\end{array}$ & Sporadic & $\mathrm{E} \times 12$ & PST & Substitution & $1520 \mathrm{G} \mathrm{G}-\mathrm{T}^{\mathrm{a}}$ & & $\begin{array}{l}\text { Frameshift from codon } 386, \\
\text { protein longer than wild type }\end{array}$ \\
\hline \multirow[t]{2}{*}{$\begin{array}{l}15 \\
(20021)\end{array}$} & \multirow{2}{*}{$\begin{array}{l}\text { I ris } 6 \\
\text { intermediate nystagmus, congenital cataract, mild } \\
\text { photophobia, glaucoma }\end{array}$} & \multirow[t]{2}{*}{ Familial } & Ex5 & Paired & Substitution & 495A $-\mathrm{CA} \mathrm{T}^{\mathrm{a}}$ & & $\begin{array}{l}\text { Frameshift, introducing stop } \\
\text { codon in exon } 6\end{array}$ \\
\hline & & & Ex10 & PST & Substitution & $1193 G-A$ & Q 277Q & Silent \\
\hline $\begin{array}{l}17 \\
(19595)\end{array}$ & $\begin{array}{l}\text { I ris } 5 \\
\text { mild nystagmus, mild corneal dystrophy, glaucoma }\end{array}$ & $\begin{array}{l}\text { Gonadal } \\
\text { mosaicism }\end{array}$ & Ex6 & Paired & $\begin{array}{l}\text { Deletion with } \\
\text { insertion }\end{array}$ & $\begin{array}{l}\text { 598delCG } \\
\text { 597ins10 }\end{array}$ & & $\begin{array}{l}\text { Frameshift, introducing stop } \\
\text { codon in exon } 6\end{array}$ \\
\hline \multirow[t]{2}{*}{$\begin{array}{l}21 \\
(18384)\end{array}$} & \multirow{2}{*}{$\begin{array}{l}\text { I ris } 4 \\
\text { mild nystagmus, early cataract, mild corneal } \\
\text { dystrophy }\end{array}$} & \multirow[t]{2}{*}{ Familial } & Ex7 & \multirow[t]{2}{*}{ Linker } & & $853 d_{e l C}^{a}$ & & $\begin{array}{l}\text { Frameshift, introducing stop } \\
\text { codon in exon } 8\end{array}$ \\
\hline & & & IVS9 & & Substitution & IV S9-12C-T & & K nown polymorphism ${ }^{42}$ \\
\hline $\begin{array}{l}27 \\
(29254)\end{array}$ & $\begin{array}{l}\text { I ris } 6 \\
\text { mild nystagmus, early cataract, severe corneal } \\
\text { dystrophy, mild photophobia, glaucoma }\end{array}$ & Sporadic & $E \times 6$ & Paired & D uplication & 718ins14 & & $\begin{array}{l}\text { Frameshift, introduction of } \\
\text { stop codon in exon } 7\end{array}$ \\
\hline $\begin{array}{l}29 \\
(29387)\end{array}$ & $\begin{array}{l}\text { I ris } 6 \\
\text { mild nystagmus, congenital cataract, mild corneal } \\
\text { dystrophy, glaucoma }\end{array}$ & Familial & $\mathrm{E} \times 7$ & Linker & D eletion & $764 \mathrm{delG}^{\mathrm{a}}$ & & $\begin{array}{l}\text { Frameshift, introduction of } \\
\text { stop codon in exon } 7\end{array}$ \\
\hline $\begin{array}{l}31 \\
(29795)\end{array}$ & $\begin{array}{l}\text { I ris } 3 \\
\text { mild nystagmus, lens ectopia }\end{array}$ & Familial & $E \times 3$ & $5^{\prime} \cup T R$ & D eletion & $246 \mathrm{del} 4^{\mathrm{a}}$ & & $?$ \\
\hline
\end{tabular}

Schematic overview of PAX 6 mutations, with phenotypes, inheritance, exon/intron location, domain location, type, nucleotide involved, codon involved and presumed protein outcome. Numbers in brackets are laboratory codes. ${ }^{a} \mathrm{~N}$ ovel mutations. 

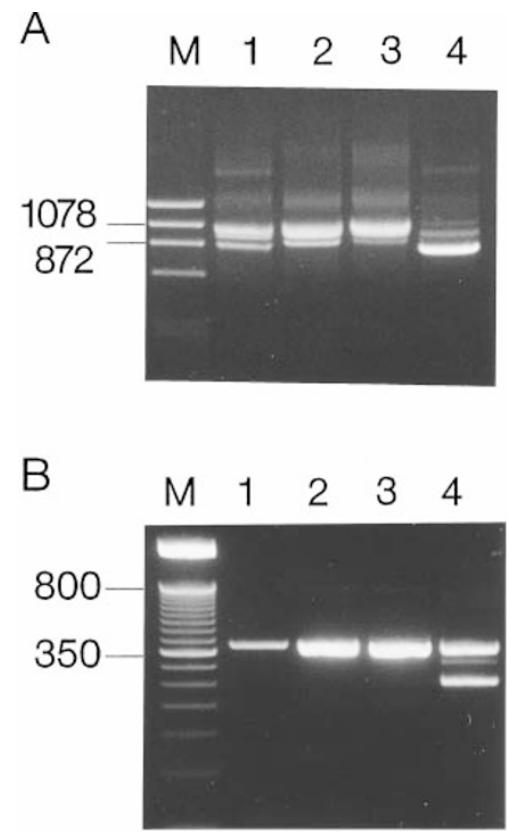

Figure 3 RT-PCR analysis of splice mutations. Nested RT-PCR analysis of CDNA from lymphoblastoid cells from patients and controls. Numbers to the left of the figure indicate marker sizes in bp. A A mplification of fragment 1 analysed on $1 \%$ SeaKem GTG agarose gel. $M$ is the PhiX $174+\mathrm{H}$ aellI molecular weight marker from $\mathrm{N}$ ew E ngland $\mathrm{Biolabs,} \mathrm{lanes} \mathrm{1-}$ 3 are normal controls and lane 4 is patient 18. Normal fragment 1 products are approximately 1055, 1013 and $855 \mathrm{bp}$. B A mplification of fragment 2 analysed on a $2 \%$ SeaK em G T G agarose gel. $L$ ane $M$ is the $50 \mathrm{bp}$ molecular weight marker from Gibco, lanes 1-3 are normal controls, and lane 4 is patient 35. Normal fragment 2 product is $375 \mathrm{bp}$

fragments, one with the expected size of $378 \mathrm{bp}$ which was also seen in controls and an additional smaller fragment of approximately $265 \mathrm{bp}$ (Figure 3B). The fragments were excised from the gel and eluted in $\mathrm{H}_{2} \mathrm{O}$ overnight and sequenced. This showed that the smaller fragment lacked exon 11. This would lead to premature termination of the protein after incorporation of 25 erroneous amino acids.

In case 30 a previously reported substitution in intron 6 was found (IVS6 + IG > A). ${ }^{33,42}$ We did not have EBV transformed lymphocytes from this patient and therefore it was not possible to do RT-PCR analysis. However, the mutation has been reported to cause usage of a cryptic splice site in exon $6{ }^{33,42}$

\section{Insertions and Deletions}

Case 3 had a substitution and a deletion in exon 12, substituting 1520G and 1521G with a single $T$ (1520G G > T). This would lead to a frameshift, and an aberrant and extended protein from codon 386.
A nother patient (case 17) had a deletion of $598 \mathrm{C}$ and 599G with an insertion of TTTGCTTACA following nucleotide 597 in exon 6 in the paired domain (598delCG, 597ins10), which would introduce a stop codon after incorporation of eight aberrant amino acids. The 10 nucleotides are identical to the inverted sequence from nucleotide 611 to 620 . The patient's brother also had aniridia, and upon sequencing he was found to have the same insertion as the patient, whereas the mutation could not be found in DNA extracted from whole blood from the healthy parents. This family most likely represents gonadal mosaicism in one of the parents.

Case 15 had a complex substitution of $495 \mathrm{~A}$ by CAT (495A > CA T), leading to a frameshift and introduction of a stopcodon in exon 6 after incorporation of 9 erroneous amino acids. Furthermore, we found a silent mutation in exon 10 in this patient substituting $1193 \mathrm{G}$ with an A.

A one base pair deletion was found in case 21 in exon 7 in the linker region (853delC). This would lead to a frameshift and premature termination in exon 8 preceded by 42 erroneous amino acids.

In case 27 we found a 14 base pair insertion in exon 6 where nucleotides 705-718, both included, were duplicated and inserted between nucleotide 718 and 719 (718ins14). This would lead to premature termination after incorporation of nine incorrect amino acids.

In case 29 we found a one base pair deletion (764delG), in exon 7 in the linker region. The mutation would cause a frameshift and premature termination after incorporation of 12 erroneous amino acids.

We also found a four base pair deletion in exon 3 (246del4) located before translation start site in case 31. It is difficult to say if this would have any effect on transcription or translation. It was not possible to do segregation analysis in this family.

\section{PAX6 Isoforms}

RT-PCR analysis of illegitimate transcripts from lymphoblastoid cells from patients and controls showed several fragments. To verify the expression pattern we studied a sample of human brain CDNA and found the same isoforms (Figure 4). Primers $1 F$ and C130 were used for the initial PCR and the nested primers used are shown in Figure 4A. A mplification with C 127 and C 860 showed four fragments of approximately $450 \mathrm{bp}$, $560 \mathrm{bp}, 610 \mathrm{bp}$ and $650 \mathrm{bp}$, which were sequenced (Figure 4B). The $650 \mathrm{bp}$ and $610 \mathrm{bp}$ bands represented 
A

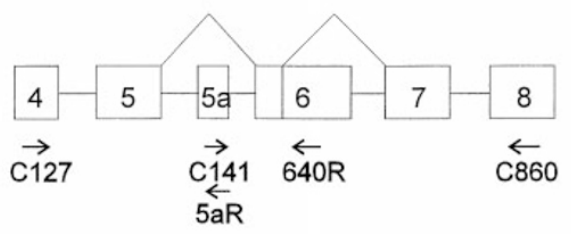

B

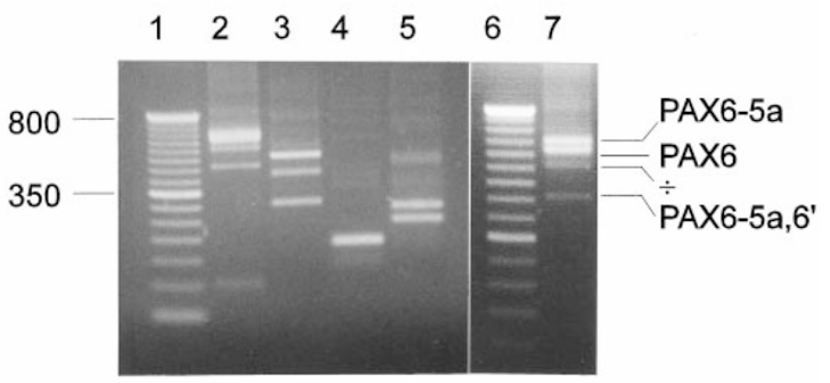

Figure 4 PA $X 6$ alternative splicing. PA X 6 isoforms in the human cerebellum investigated by nested RT-PCR analysis. $\mathbf{A}$ Schematic figure of exons 4 to 8 of $P A X 6$ showing the alternative splice sites and primers used for nested PCR. N ot drawn to scale. B First round PCR was performed with primers $1 F$ and $C 130$. Nested PCR products were analysed on a 2\% SeaKem GTG agarose gel. L ane 1: $50 \mathrm{bp}$ ladder from G ibco, lane2: primers C 127 and C 860, lane3: primers C 141 and $C 860$, lane 4: primers $\mathrm{C} 127$ and $5 \mathrm{aR}$, lane 5: primers $\mathrm{C} 127$ and 640R. Primers C130, C127, C 860 and C 141 were from $\mathrm{H}$ anson et al $1993 .^{33} \mathrm{~L}$ anes 6 and 7 are longer runs of lane 1 and 2 demonstrating clear separation of $610 \mathrm{bp}$ and $650 \mathrm{bp}$ bands

the PA X 6-5a and the canonical PAX 6 isoforms respectively. The $450 \mathrm{bp}$ fragment represented the PA $\times 6-5 a, 6^{\prime}$ isoform containing exon 5 a, but using an alternative $5^{\prime}$ splice site in exon 6 , thereby including only $15 \mathrm{bp}$ of exon 6. The alternative $5^{\prime}$ splice site in exon 6 was previously reported for bovine eye ${ }^{20}$ and quail, ${ }^{21}$ but to our knowledge not in humans. A ttempts to sequence the $560 \mathrm{bp}$ fragment failed, furthermore this fragment was not amplified regularly, and it could represent mispriming. This was also the case for the $430 \mathrm{bp}$ fragment amplified with primers C 141 and C 860 . PCR amplification with various primer combinations showed the expected fragment sizes (Figure 4B).

\section{Discussion}

Mutations in the paired box gene PAX 6 have been recognised as the genetic cause of aniridia. Pax- 6 has been extremely well conserved through evolution, and both the mouse Pax- 6 gene and the ascidian Phallusia mammillata Pax- 6 gene were able to induce eye formation in D rosophila. ${ }^{16,46}$ It is assumed that aniridia arises from haploinsufficiency based on the phenotypical resemblance of individuals deleted for one copy of the gene and intragenic mutations.

We identified mutations in 18 of 23 aniridia patients. No mutations were found in three congenital cataracts and one Peter's anomaly patients.

The reason we did not detect mutations in all aniridia patients could be methodological, ie the sensitivity of the dideoxy fingerprinting method. A nother possibility is that the mutations are located outside the examined region, for example in the promoter region or in intron sequences distant from the splice sites. Furthermore, it has been shown that alterations in sequences distant from the PAX 6 gene can cause aniridia, as seen from two translocation patients described by Fantes et al, ${ }^{47}$ where the translocation breakpoint was located at least $85 \mathrm{~kb}$ from the PAX 6 gene. Phenocopy or other genetic causes could be a possibility especially in congenital cataract and Peter's anomaly.

Eleven of the described mutations were predicted to cause premature truncation of PAX 6 (cases 15, 17, 21, $22,27,29,32,34$ and 35 ) or to abolish translation (cases 16 and 30 ), and were expected to give a severe phenotype. Indeed nine of them scored iris 5 or 6 . The mutation found in case 3 would be expected to result in translation beyond the normal stop codon. The phenotype was moderately mild (iris 3 ), and possibly the PA $X 6$ protein retains some of its activity. A $n$ extended PAX 6 protein has been reported previously in a familial case of aniridia. ${ }^{33}$

A $n$ interesting case was 31 where we found a 4 base pair deletion in exon 3 upstream of the ATG initiation codon. This is the first variation found in exon 3 to our knowledge. However, since we did not have the opportunity to analyse family members, we cannot be sure that this mutation is the disease-causing factor, or a polymorphism.

A striking question has been why so few missense mutations have been identified so far in the PAX 6 gene. A mong the 118 mutations reported in the PAX 6 mutation database, ${ }^{31}$ only six are missense mutations, of which four were reported to have a deviant (nonaniridia) phenotype, whilst there are around 70 other single base pair substitutions reported. A PA X 6 protein with an amino acid substitution could still retain some residual activity depending on the type and position of 
the amino acid exchange and result in partial haploinsufficiency. It has been shown in the bovine eye that the $5 a$ isoform predominates in the iris in contrast to the lens and retina where PAX 6 and PAX 6-5a seem to be equally represented, ${ }^{20}$ indicating that the PAX6-5a isoform is important for iris development. This is interesting since four of our missense mutations are located outside the helices in the $\mathrm{C}$-terminal subdomain thought to make DNA contact in PAX 6-5a, and these patients all show a mild iris phenotype, whereas the lenses were affected. Furthermore, we identified a third PAX 6 isoform PAX 6-5a,6' in human cerebellum (Figure 4) also present in lymphoblastoid cells, in which two of the four missense mutations would be spliced out and consequently not affect the function of this isoform. A third missense mutation was located in the alternative $5^{\prime}$ splice site in exon 6 , and consequently would result in absence of the PAX 6-5a,6' isoform. These results support the hypothesis that missense mutations in PAX 6 could cause deviant phenotypes. $O$ ne patient with a missense mutation was ranked as an iris 6 (case 16, M 1K). H owever, this must be considered a null allele, since the mutation disrupts the initiation codon (ATG changed to $A A G$ ), and this has been shown from other genes to abolish translation. ${ }^{48-50}$

A niridia has always been considered to be fully penetrant, but with great variation in expressivity. In the present investigation we present evidence for a non-penetrant mutation, a mutation with variable expressivity, as well as gonadal mosaicism. The nonpenetrant PAX 6 mutation (R 208Q) was found in the healthy mother of case 4 who was a compound heterozygote for two missense mutations. That the R 208Q mutation is non-penetrant is unexpected, because of the extreme conservation of the PAX 6 gene through evolution. Moreover, arginine 208 has been found mutated to a tryptophan (R 208W) in an affected female and her affected son. ${ }^{33}$ It could be argued, however, that a change to glutamine is less radical than a change to tryptophan based on the resemblance of the side chains. Indeed, if both missense mutations caused nonfunctional PA $X 6$ proteins, a more severe phenotype of case 4 and her siblings would be expected, ${ }^{24}$ in fact case 4 displays a very mild phenotype. This is also an argument against the possibility of the mother having the mutation in a mosaic form.

A rginine 208 is part of four amino acid motif (LKRK) located just upstream of the homeodomain which was thought to be conserved in all PAX genes with an intact homeodomain. However, recently the cloning of PAX 4 showed that the motif is not conserved in this gene. ${ }^{51}$ In vitro experiments using transfected COS7 cells showed that the R 208W mutation prevented nuclear localisation of PAX $6{ }^{52}$ whilst similar experiments in quail showed normal nuclear localisation, ${ }^{53}$ leaving some uncertainty of the biological consequences of the R 208W mutation.

G onadal mosaicism was probably the explanation for the transmission in the family of case 17 in whom a deletion and insertion event had taken place (598delCG , 597ins10). The same mutation was present in an affected brother but not in the parents. Microsatellite analysis with four polymorphic markers (WT 1, D 11S929, D 11S2071 and TH, data not shown) showed no contradiction of the parents being the biological parents of the two children.

This paper confirms the phenomenon of variable expressivity, since we found two patients with the same nonsense mutation ( $R 317 X$ ), but whereas one patient scored iris6, the other showed a notably milder phenotype and was classified as iris 3. The patient with the milder phenotype was a sporadic case, and mosaicism could be considered as a possible explanation. However, variable phenotypes within a family have been described ${ }^{54}$ indicating that other factors than the mutated PA X 6 protein contributes to phenotype. Some stochastic variation in expression must exist and a disease caused by haploinsufficiency could be expected to be very sensitive to such fluctuations.

In conclusion, our investigation of a large number of clinically well characterised aniridia patients showed a relatively large percentage with missense mutations, associated especially with mild phenotypes, but early cataract. This further strengthens the concept of a dosage effect of PAX 6 mutations.

Variable expressivity and apparently non-penetrance were also observed, indicating that other factors than PAX 6 mutations may influence the phenotype.

\section{Acknowledgements}

We are indebted to $D$ anish ophthalmologists who made their observations available for this study. We would also like to thank all the families for participating in this study. We would like to thank Winni Pedersen for expert technical assistance and Preben $\mathrm{Holst}$ and $\mathrm{Helle}$ Lauersen for help with the figures. This work was supported by grants from $V æ r$ om Synet, B lindes Støttefond, Cykelhandler PTh R asmussen and 
hustru A Ima R asmussens mindelegat, and the Danish Medical Research Council.

\section{References}

$1 \mathrm{H}$ anson I, van $\mathrm{H}$ eyningen $\mathrm{V}$ : PAX 6: more than meets the eye. Trends $\mathrm{G}$ enet 1995; 11: 268-272.

2 van $\mathrm{H}$ eyningen $\mathrm{V}, \mathrm{H}$ astie ND: Wilms' tumour: reconciling genetics and biology. Trends $\mathrm{G}$ enet 1992; 8: 16-21.

3 Ton $\mathrm{CC}, \mathrm{H}$ irvonen $\mathrm{H}, \mathrm{M}$ iwa $\mathrm{H}$ et al: Positional cloning and characterization of a paired box- and homeobox-containing gene from the aniridia region. Cell 1991; 67: 1059-1074.

4 Walther C, Gruss P: Pax-6, a murine paired box gene, is expressed in the developing CNS. D evelopment 1991; 113: 1435- 1449.

5 Ton CC, M iwa H, Saunders G F : Small eye (Sey): cloning and characterization of the murine homolog of the human aniridia gene. G enomics 1992; 13: 251-256.

$6 \mathrm{M}$ artin $\mathrm{P}, \mathrm{C}$ arriere $\mathrm{C}, \mathrm{D}$ ozier $\mathrm{C}$ et al: Characterization of a paired box- and homeobox-containing quail gene (PaxQNR) expressed in the neuroretina. O ncogene 1992; 7: 1721-1728.

7 M atsuo T, O sumi Yamashita N, Noji S et al: A mutation in the Pax- 6 gene in rat small eye is associated with impaired migration of midbrain crest cells. Nat G enet 1993; 3: 299-304.

8 Li H S, Y ang J M, Jacobson R D, Pasko D, Sundin O : Pax-6 is first expressed in a region of ectoderm anterior to the early neural plate: implications for stepwise determination of the lens. D ev Biol 1994; 162: 181-194.

9 Krauss $S$, Johansen $T$, Korzh $V$, M oens $U$, Ericson JU, Fjose A : Zebrafish pax[zf-a]: a paired box-containing gene expressed in the neural tube. EMBO J 1991; 10: 3609-3619.

10 Puschel AW, Gruss P, Westerfield $M$ : Sequence and expression pattern pax- 6 are highly conserved between zebrafish and mice. D evelopment 1992; 114: 643-651.

11 Q uiring R, Walldorf U, K loter U, G ehring WJ : H omology of the eyeless gene of $D$ rosophila to the Small eye gene in mice and A niridia in humans [see comments]. Science 1994; 265: 785-789.

12 Czerny T, B usslinger M : D NA -binding and transactivation properties of Pax- 6 : three amino acids in the paired domain are responsible for the different sequence recognition of Pax-6 and BSA P (Pax-5). Mol C ell B iol 1995; 15: 2858-2871.

13 Chisholm AD, Horvitz HR: Patterning of the Caenorhabditis elegans head region by the Pax- 6 family member vab-3. Nature 1995; 377: 52-55.

14 Zhang $Y, E$ mmons SW: Specification of sense-organ identity by a Caenorhabditis elegans Pax- 6 homologue. Nature 1995; 377: 55-59.

15 L oosli F, K mita Cunisse M, Gehring WJ : I solation of a Pax-6 homolog from the ribbonworm $L$ ineus sanguineus. Proc Natl A cad Sci USA 1996; 93: 2658-2663.

16 G lardon S, Callaerts P, H alder G, G ehring WJ : Conservation of Pax- 6 in a lower chordate, the ascidian Phallusia mammillata. D evelopment 1997; 124: 817-825.
$17 \mathrm{H}$ irsch N, H arris WA : X enopus Pax-6 and retinal development. J Neurobiol 1997; 32: 45-61.

18 Glaser T, Walton DS, M aas RL: Genomic structure, evolutionary conservation and aniridia mutations in the human PAX 6 gene. $N$ at G enet 1992; 2: 232-239.

19 Epstein JA, G laser T, Cai J, Jepeal L, Walton DS, M aas $R L$ : Two independent and interactive DNA -binding subdomains of the PAX 6 paired domain are regulated by alternative splicing. G enes D ev 1994; 8: 2022-2034.

20 Jaworski C, Sperbeck S, G raham C, Wistow G : A Iternative splicing of PAX 6 in bovine eye and evolutionary conservation of intron sequences. Biochem Biophys Res Comm 1997; 240: 196-202.

21 Carriere C, Plaza S, M artin P et al: Characterization of quail Pax-6 (Pax-Q NR) proteins expressed in the neuroretina. M ol Cell Biol 1993; 13: 7257-7266.

22 Mermod N, O'Neill EA, Kelly TJ, Tijan R: The prolinerich transcriptional activator of CTF/NF-I is distinct from the replication and DNA binding domain. Cell 1989; 58: 741-753.

23 Tanaka $M$, Herr W: D ifferential transcriptional activation by $\mathrm{Oct}-1$ and $\mathrm{Oct}-2$ : interdependent activation domains induce O ct-2 phosphorylation. Cell 1990; 60: 375-386.

24 G laser T, J epeal L, E dwards J G, Y oung SR, Favor J, M aas $R L$ : PAX 6 gene dosage effect in a family with congenital cataracts, aniridia, anophthalmia and central nervous system defects [published erratum appears in Nat $\mathrm{G}$ enet 1994 O ct; 8(2): 203]. Nat G enet 1994; 7: 463-471.

25 Tang HK, Singh S, Saunders G: Dissection of the transactivation function of the transcription factor encoded by the eye development gene PA X 6. J B iol Chem 1998; 273: 7210-7221.

26 Plaza S, Dozier C, Saule S: Quail Pax-6 (Pax-QNR) encodes a transcription factor able to bind and transactivate its own promoter. Cell Growth Differ 1993; 4: 1041-1050.

27 Callaerts P, H alder G, G ehring W J : PA X -6 in development and evolution. A nnu Rev Neurosci 1997; 20:00-00

28 Wehr R, G russ P: Pax and vertebrate development. Int J Dev Biol 1996; 40: 369-377.

29 Bopp D, Burri M, B aumgartner S, Frigerio G, Noll M: Conservation of a large protein domain in the segmentation gene paired and in functionally related genes of Drosophila. Cell 1986; 47: 1033-1040.

$30 \mathrm{Hill} R \mathrm{RE}$, Favor J, Hogan BL et al: Mouse small eye results from mutations in a paired-like homeobox-containing gene [published erratum appears in Nature 1992 Feb 20; 355(6362):750]. Nature 1991; 354: 522-525.

31 Brown $A, M c K$ ie $M$, van Heyningen $V$, Prosser J: The human PAX 6 mutation database. Nucleic A cids R es 1998; 26: 259-264.

32 Prosser J, van Heyningen V: PAX 6 mutations reviewed. H um M utat 1998; 11: 93-108.

$33 \mathrm{H}$ anson IM, Seawright $A, H$ ardman $K$ et al: PAX 6 mutations in aniridia. H um M ol G enet 1993; 2: 915-920.

34 Tang HK, Chao LY, Saunders G F : Functional analysis of paired box missense mutations in the PAX 6 gene. $\mathrm{H}$ um M ol G enet 1997; 6: 381-386.

$35 \mathrm{H}$ anson IM, Fletcher J M, Jordan T et al: $M$ utations at the PAX 6 locus are found in heterogeneous anterior segment malformations including Peters' anomaly. N at G enet 1994; 6: 168-173. 
36 A zuma N, Nishina S, Y anagisawa $\mathrm{H}, \mathrm{O}$ kuyama T, Y amada $M$ : PAX 6 missense mutation in isolated foveal hypoplasia. $\mathrm{N}$ at $\mathrm{G}$ enet 1996; 13: 141-142.

37 A zuma $N$, Yamada $M$ : Missense mutation at the $C$ terminus of the PAX 6 gene in ocular anterior segment anomalies. Invest O phthalmol Vis Sci 1998; 39: 828-830.

38 M irzayans F, Pearce W G, M acD onald IM, Walter MA: Mutation of the PAX 6 gene in patients with autosomal dominant keratitis. A m J H um G enet 1995; 57: 539-548.

39 Miller SA, Dykes DD, Polesky HF: A simple salting out procedure for extracting DNA from human nucleated cells. Nucleic A cids R es 1988; 16: 1215.

40 Maas RL, Epstein JA, G laser $T$ : Identification and functional analysis of mutations in the human PAX 6 gene. M ethods M ol G enet 1996; 8: 40-69.

41 Sarkar G, Sup H-S, Sommer SS: Dideoxy fingerprinting $(d d F): A$ rapid and efficient screen for the presence of mutations. G enomics 1992; 13: 441-443.

42 A xton $\mathrm{R}, \mathrm{H}$ anson I, D anes $\mathrm{S}$, Sellar $\mathrm{G}$, van $\mathrm{H}$ eyningen $\mathrm{V}$, Prosser $\mathrm{J}$ : The incidence of PAX 6 mutation in patients with simple aniridia: an evaluation of mutation detection in 12 cases. J M ed G enet 1997; 34: 279-286.

$43 \mathrm{Xu} \mathrm{W}$, Rould M A, Jun S, D esplan C, Pabo CO : Crystal structure of a paired domain-DNA complex at $2.5 \mathrm{~A}$ resolution reveals structural basis for Pax developmental mutations. Cell 1995; 80: 639-650.

$44 \mathrm{D}$ avis $\mathrm{A}$, Cowell JK: Mutations in the PAX6 gene in patients with hereditary aniridia. $\mathrm{H}$ um M ol G enet 1993; 2: 2093-2097.

45 Churchill A J, A nwar R, M arkham A F : PAX 6, aniridia and Peters' anomaly. [A bstract] Invest O phtalmol Vis Sci 1997; 38: (4) 112-B 23.

$46 \mathrm{H}$ alder G, Callaerts P, G ehring WJ : Induction of ectopic eyes by targeted expression of the eyeless gene in D rosophila [see comments]. Science 1995; 267: 1788-1792.

47 Fantes $\mathrm{J}$, Redeker $B, B$ reen $M$ et al: A niridia-associated cytogenetic rearrangements suggest that a position effect may cause the mutant phenotype. $\mathrm{H}$ um M ol G enet 1995; 4 : 415-422.

48 E iken H G, K nappskog PM , A pold J, Skjelkvåle L, B oman $\mathrm{H}: \mathrm{A}$ de novo phenylketonuria mutation: ATG (Met) to ATA (Ile) in the start codon of the phenylalanine hydroxylase gene. Hum M utat 1992; 1: 388-391.

49 Saba L, M eloni A, Sardu R et al: A novel b-thalassemia mutation (G-A) at the initiation codon of the b-globin gene. $\mathrm{H}$ um M utat 1992; 1: 420-422.

50 Sistermans EA, de Wijs IJ, de Coo RFM, Smit LME, Menko $F H$, van Oost BA: A (G-to-A) mutation in the initiation codon of the proteolipid protein gene causing a relatively mild form of Pelizaeus-M erzbacher disease in a D utch family. H um G enet 1996; 97: 337-339.

51 Inoue $H$, N omiyama J, Nakai $K$, M atsutani A, Tanisawa $Y$, $O \mathrm{ka} Y$ : I solation of full-length CDNA of mouse PAX 4 gene and identification of its human homologue. Biochem Biophys Res Comm 1998; 243: 628-633.

52 G laser T, Walton DS, Cai J et al: PAX 6 gene mutations in A niridia. In: Wiggs J L (ed.). M olecular $G$ enetics of $O$ cular D isease. Wiley-Liss: N ew Y ork, 1995, vol 3, pp 51-82.

53 Carriere C, Plaza S, Caboche J et al: Nuclear localization signals, DNA binding, and transactivation properties of quail Pax-6 (Pax-Q NR ) isoforms. Cell Growth D iffer 1995; 6: $1531-1540$.
$54 \mathrm{M}$ artha $A$, Ferrell RE, Mintz $H$ ittner $H$, Lyons $L A$, Saunders GF: Paired box mutations in familial and sporadic aniridia predicts truncated aniridia proteins [published erratum appears in A m J H um G enet 1994 Sep; 55(3):602]. A m J H um G enet 1994; 54: 801-811.

\section{Appendix}

\section{Clinical Case Histories}

Case 3 I ris3. Sporadic case, female born 1983. A three $\mathrm{mm}$ preserved zone of iris tissue was present in the whole circumference leaving a large, centrally situated pupil. Congenital cataracts were aspirated during the first year of life. G laucoma developed due to goniosynecchias. Both corneas measured $8 \mathrm{~mm}$ horizontally and epithelial metaplasia was significant. At the age of 13 both corneas were completely vascularised. Visual acuity (1995) right eye: 0.03 with $+12.0 \mathrm{sph}$. $-1.75 \mathrm{cyl} . \times 180^{\circ}$, left eye: light perception +12.0 sph. -1.75 cyl. $\times 0^{\circ}$.

Case 4 I ris2. Familial case, female born in 1974. This patient had a mild phenotype with upward and nasal deplacements of both pupils, nystagmus and foveal hypoplasia. A t birth she had no lens opacities but she developed early cataract and underwent surgery with insertion of posterior chamber lenses at the age of 21. The corneas had normal diameter and no sign of vascularisation was present. $V$ isual acuity on both eyes (1996) was $0.1+5.00 \mathrm{sph}$. The affected father and an affected sister had very similar phenotypes, whilst an affected brother had bilateral, atypical iris coloboma (iris4).

Case 5 Iris 3. Familial case, female born in 1990. $D$ uring the first year of life faint nystagmus was present but later on it almost disappeared. Circumpupillary iris aplasia with fine strands crossing the pupillary area. No marginal corneal dystrophy, cataract or lens dislocation were present. She had moderate photophobia, normal looking optical nerve heads and preserved foveal reflexes. Visual acuity on both eyes was $0.3+2.00 \mathrm{sph}$.

Case 13 Iris 3-4. Familial case, female born 1957. $D$ istinct nystagmus and cataract were present soon after birth. In the right eye stromal iris hypoplasia and an atypical coloboma from 7 to 9 o'clock was found. The left eye had circumpupillary iris aplasia with residual iris in the whole periphery. She underwent cataract surgery in 1987 and 1988. In her right eye a posterior chamber lens was inserted. Her left eye 
remained aphakic. A t the age of 35 a $2 \mathrm{~mm}$ peripheral corneal vascularisation had emerged. Her optic nerve heads and the foveal regions looked slightly hypoplastic. A fter surgery her visual acuity was 0.16 . Seven years later it was 0.08 and 0.05 on the right eye and left eye. The refraction on the right eye was $+15.00 \mathrm{sph}$., left eye $+3.50 \mathrm{sph}$.

Case 15 Iris6. Familial case, female born in 1954. Pronounced horizontal nystagmus, total aniridia, transparent small corneas measuring $8.5-9 \mathrm{~mm}$ horizontally, and cataracts with zonular and posterior cortical opacities were present during her childhood. Cataract discission was performed when she was 18years old. Goniscopy revealed rudimentary iris remnants and whitish fibrous material in the anterior chamber angle and at 28 years of age she developed glaucoma. Only mild photophobia was present. Visual acuity on both eyes was 0.1 in 1965 and improved after cataract surgery to $0.25+12.00 \mathrm{sph}$.

Case 16 I ris6. Familial case, female born 1944 with total aniridia and moderate nystagmus. B oth crystalline lenses were upward temporally displaced with scattered opacities. She underwent cataract extractions at the age of 39 and 40 . V isual acuity on both eyes (1952) was 0.1 with $-5.0 \mathrm{sph}$. right eye and $-8.0 \mathrm{sph}$. left eye.

Case 17 I ris 5. Female born in 1976. Iris remnants were found temporally in both eyes. In addition: moderate nystagmus was present and a $2 \mathrm{~mm}$ concentric vascularised corneal rim, mesenchymal structures occupying part of the iridocorneal angle, posterior stellate lens opacities, and foveal hypoplasia. A left esotropia was operated on in 1978. Visual acuity right eye: $0.1+5.0 \mathrm{sph}$., left eye: $0.1+6.0 \mathrm{sph}$. A brother had an almost identical phenotype, whilst neither of the parents had iris anomalies or other ocular signs of being affected.

Case 18 I ris5. Familial case, male born 1961. I ris structures were visible upwards temporally in both eyes. A fine horizontal nystagmus was present. Superficial limbal corneal dystrophy, moderate dysgenesis of the anterior chamber angle, and posterior cortical cataracts were also present. Cataract extractions were performed in 1985 and 1987. The foveal reflexes were present. Visual acuity on both eyes (1970): 0.25 with +7.0 sph. $-2.0 \mathrm{cyl}$. $\times 90^{\circ}$.

Case 21 I ris 4. Familial case, male born 1920. A t 14 years old he underwent cataract extraction on both eyes. L eft eye was enucleated 8 years later. A right eye photography revealed an atypical coloboma in upward temporal direction intersecting the limbus from 9 to 11 o'clock. Corneal hypervascularisation was treated by strontium 90 irradiation in 1965. A slight rotatoric nystagmus was present. Visual acuity (1938) right eye: 0.1 with $+10.0 \mathrm{sph}$.

Case 22 I ris 6. Familial case, male born in 1965 with typical aniridia without any visible iris structures, undulating nystagmus, upward nasally displaced lenses with a few stromal opacities and an inferior coloboma of the left lens. Spontaneous aphakia occurred. Both eyes had microcornea with a $2 \mathrm{~mm}$ rim of marginal vascularisation. In addition an inferior uveal coloboma was present in the fundus of the right eye. $V$ isual acuity was 0.1 on both eyes (1975).

Case 23 Iris2. Familial case, male born 1958 with ectopia of the pupils (right eye: upwards nasally, left eye: downward nasally), and vigorous nystagmus. Cataract developed early and was extracted from the right eye at the age of 30. A slight marginal corneal dystrophy was noticed at the age of 25. A nterior chamber angles were wide and a fibrous mass partially obscuring the trabecular meshwork. Complicating glaucoma was diagnosed in his twenties. Visual acuity (1983) was reduced to 0.02 on both eyes.

Case 27 Iris6. Sporadic case, male born 1965. By slit lamp examination no iris structures were seen. $\mathrm{N}$ evertheless, gonioscopy disclosed a slender iris remnant upwards in the chamber angle. The trabecular meshwork was whitish and looked fibrous behind a band shaped pigmented veil. No goniosynecchias were present. Glaucoma was diagnosed at the age of 10. During the following 9 years he underwent several operations including cyclodiathermy, trabeculectomy, cataract extraction and corneal transplantations. V isual acuity on both eyes (1978): 0.1 with +6.0 sph .

Case 29 Iris6. Familial case, female born 1955. $\mathrm{Nystagmus}$ and aniridia were diagnosed shortly after birth. Close ophthalmological control since the age of 6 months. A t the initial examination complete aniridia and dense zonular cataracts were found. Gonioscopy revealed small iris remnants, open anterior chamber angles with membranaceous tissue strands. Complicating glaucoma was diagnosed before 1 year of age. At 10 years her visual acuity was 0.1 on both eyes. A t age 35 the visual acuity had dropped to 0.01 , and at the last 
examination in 1997 only hand movements were recorded from her right eye, whilst visual acuity on the left eye remained unchanged. Cataract extraction was performed at age 40. Preoperatively axial lengths of $24.8 \mathrm{~mm}$ and $24.5 \mathrm{~mm}$ were measured in right and left eyes. The corneas remained completely clear during the first 30 years, but 10 years later marginal and central corneal degeneration and scarring had developed.

Case 30 Iris6. Familial case, female born in 1952. $\mathrm{N}$ ystagmus and total aniridia were observed soon after birth. Later, lens dislocation, lens coloboma, and posterior corneal and zonular cataracts were noticed. G laucoma was diagnosed at the age of 8 years and was treated intensely by medication and surgically. D espite treatment, visual acuity deteriorated and in 1972 a blind, painful right eye was enucleated. Histopathological examination revealed rudimental iris tissue which adhered to a fibrous trabecular meshwork. The optic nerve head was deeply excavated. The cornea seemed to lack Bowman's membrane and a few peripheral vessels were present in the peripheral part of the corneal stroma. Later on, her left eye developed marginal corneal vascularisation and opacification. In 1962 the visual acuity was 0.1 on both eyes. In 1997 the visual acuity of the left eye was 0.01 and her visual field was restricted to the $20^{\circ}$ isopter.

Case 31 Iris3. Familial case, male born 1959. The iris displayed a peripupillar aplasia leaving a large centrally situated pupil surrounded by a $3 \mathrm{~mm}$ iris structure. O ther signs were fine undulating nystagmus, upward dislocated lenses, and a right eye posterior cataract. The left eye had scattered peripheral stromal opacities. Foveal hypoplasia was noted but there was no sign of corneal dystrophy or vascularisation. Visual acuity was 0.3 on both eyes (1997).

Case 32 Iris6. Familial case, female born 1960. A full-blown phenotype was seen including total aniridia, nystagmus, foveal hypoplasia, greyish hypoplastic optic nerve heads, mild marginal corneal dystrophy, and posterior polar cataracts. Visual acuity (1976) right eye $0.1+3.0 \mathrm{sph}$. $-1.5 \mathrm{cyl} . \times 0^{\circ}$, left eye $0.1+5.0 \mathrm{sph}$. $-3.0 \mathrm{cyl} . \times 0^{\circ}$.

Case 34 Iris3. Sporadic case, female born 1986. Incomplete aniridia including peripupillary iris aplasia resulting in enlarged pupils crossed by tread-like foetal remnants. Coarse nystagmus was present. The corneas were large $(12.5 \mathrm{~mm})$ with a mild peripheral epithelial dystrophy. Both crystalline lenses had anterior polar cataracts. Foveal hypoplasia and slight hypoplastic optic nerve heads were seen ophthalmoscopically. Visual acuity on both eyes (1992) was 0.1 with $-8.0 \mathrm{sph}$.

Case 35 Iris5. Familial case, male born 1944. Sickle-shaped iris remnants were located upwardnasally. Nystagmus, conspicuous marginal corneal dystrophy, slight posteriorly situated opacities in both crystalline lenses, and foveal hypoplasia were observed. $V$ isual acuity (1953) right eye: 0.2 with +2.0 sph., left eye: 0.25 with +3.0 sph. 